\title{
PENGARUH PENGGUNAAN KELAPA HIJAU (Cocos nucifera L.) SEBAGAI INKUBATOR PEMBUATAN YOGHURT TERHADAP UJI ORGANOLEPTIK
}

\author{
MAKSUM, M. M. H., I N. S. MIWADA., DAN S. A. LINDAWATI \\ Fakultas Peternakan Universitas Udayana \\ e-mail: hafidzmaksum@student.unud.ac.id
}

\begin{abstract}
ABSTRAK
Penelitian ini dilakukan untuk mengetahui hasil uji organoleptik yoghurt yang diinkubasi menggunakan inkubator berbeda. Penelitian ini dilaksanakan pada bulan Januari hingga Maret 2020 di Laboratorium Mikrobiologi dan Teknologi Hasil Ternak Fakultas Peternakan Universitas Udayana. Rancangan percobaan berupa Rancangan Acak Lengkap (RAL) dengan tiga perlakuan dan lima ulangan yaitu inkubator berupa wadah vakum biasa (toples) (Po), inkubator berupa kelapa hijau muda (Cocos nucifera L.) tanpa daging (P1), dan inkubator berupa kelapa hijau muda (Cocos nucifera L.) berisi daging (P2). Variabel yang diamati meliputi warna, aroma, citarasa, tekstur, dan penerimaan keseluruhan. Hasil uji organoleptik dianalisis menggunakan uji Kruskal Wallis dan apabila terdapat perbedaan nyata $(\mathrm{P}<0,05)$, maka dilanjutkan dengan uji Mann-Whitney. Hasil penelitian pada kesukaan panelis terhadap warna, aroma, citarasa dan penerimaan keseluruhan yoghurt pada perlakuan Po, P1, dan $\mathrm{P} 2$ menunjukkan perbedaan yang tidak nyata $(\mathrm{P}>0,05)$. Nilai kesukaan panelis terhadap tekstur yoghurt pada perlakuan $\mathrm{P} 1$ tidak berbeda nyata $(\mathrm{P}>0,05)$ dengan semua perlakuan, namun perlakuan Po berbeda nyata $(\mathrm{P}<0,05)$ dengan perlakuan P2. Hasil penelitian ini dapat disimpulkan bahwa panelis lebih menyukai tekstur yoghurt pada perlakuan P2. Penggunaan inkubator berupa kelapa hijau muda (Cocos nucifera L.) berisi daging memberikan nilai terbaik pada uji orgenoleptik yoghurt.
\end{abstract}

Kata kunci: yoghurt, inkubator, kelapa hijau muda, uji organoleptik

\section{THE EFFECT OF USING COCOS NUCIFERA L. AS AN INCUBATOR FOR MAKING YOGHURT ON ORGANOLEPTIC TEST}

\begin{abstract}
This research was conducted to determine the value of organoleptic test on yoghurt incubated with different incubators. Conducted on January up to March 2020 at the Laboratory of Microbiology and Animal Product Technology Faculty of Animal Science, Udayana University. The experimental design is Completely Randomized Design by three treatments and five replications, those incubators are ordinary vacuum container (Po), green coconut (Cocos nucifera L.) without flesh (P1), and green coconut (Cocos nucifera $\mathrm{L}$.) with flesh (P2). The variable observed is color, aroma, flavor, texture, and overall acceptances. The organoleptic test value analyzed using Kruskal Wallis test and if there some significantly differences $(\mathrm{P}<0,05)$, it would be continued by Mann-Whitney test. The result of panelists preference to the color, aroma, flavor, and overall acceptance of yoghurt in Po, P1, and $\mathrm{P} 2$ treatments showed no significant differences $(\mathrm{P}>0,05)$. The panelists preference to the texture of yoghurt was not significantly different $(\mathrm{P}>0,05)$ on $\mathrm{P} 1$ with $\mathrm{Po}$, and $\mathrm{P} 2$ treatments, but $\mathrm{Po}$ was significantly different $(\mathrm{P}<0,05)$ with the P2 treatment. This research can be concluded that the panelists preferred to the texture of yoghurt in P2 treatment. The green coconut (Cocos nucifera L.) with flesh ( $\mathrm{P} 2)$ gives the best value in the organoleptic test.
\end{abstract}

Key words: yoghurt, incubator, green coconut, organoleptic test

\section{PENDAHULUAN}

Susu merupakan makanan alami yang hampir sempurna, sebab memiliki kandungan zat gizi esensial yang berupa protein, kalsium, fosfor, vitamin A, dan tiamin (vitamin B1) (Almatsier, 2002). Menurut Usmiati dan Abubakar (2009), susu adalah bahan pangan yang mudah rusak karena merupakan media terbaik bagi pertumbuhan mikroorganisme, sehingga memerlukan penanganan dan pengolahan yang tepat. 
Salah satu penanganan dalam mencegah kerusakan susu dilakukan proses fermentasi menjadi yogurt. Yoghurt merupakan produk fermentasi dari susu yang terbentuk akibat adanya aktivitas mikroorganisme (Heriyadi, 2016). Proses fermentasi susu menjadi yoghurt disebabkan oleh adanya simbiosis obligat antar bakteri asam laktat (BAL) yaitu Lactobacillus bulgaricus dan Streptococcus thermophilus (Helferich dan Westhoff, 1980). Lactobacillus bulgaricus dalam yoghurt dapat mengurangi kandungan racun yang terdapat dalam saluran pencernaan (Koswara, 2009).

Penggunaan mikroorganisme yang berbeda, bahan, dan/atau proses yang dilakukan dalam pembuatan susu fermentasi akan menghasilkan produk dengan rasa dan karakteristik yang berbeda (Heriyadi, 2016). Penambahan sukrosa, fruktosa, glukosa atau gliserol dapat meningkatkan kualitas susu fermentasi (Tamime dan Robinson, 1989). Pada umumnya, proses pembuatan yoghurt hanya menggunakan wadah vakum sebagai inkubatornya, namun penggunaan bahan alami sebagai inkubator masih jarang dilakukan dalam pembuatan yoghurt, sehingga dalam penelitian ini kelapa hijau muda (Cocos nucifera L.) digunakan sebagai inkubator dalam proses pembuatan yoghurt.

Kelapa memiliki kandungan gula berupa glukosa, sukrosa, dan fruktosa (Hieronymus, 1998). Direktorat Gizi Depkes RI (1981), menyatakan bahwa kelapa memiliki enzim yang dapat mengurangi sifat racun. Kelapa juga memiliki kandungan tanin atau antidotum yang berguna sebagai anti racun, namun kandungan tersebut lebih banyak ditemukan pada kelapa hijau (Cocos nucifera L.) (Kurniati, 2010). Kelapa hijau mengandung lemak, protein, karbohidrat, serat, dan juga abu sebanyak 70,6\%, 7,1\%, 17,4\%, 3,4\%, dan 1,4\% (Puspita, 2007). Penelitian ini bertujuan untuk mengetahui pengaruh penggunaan kelapa hijau muda (Cocos nucifera L.) sebagai inkubator alami dalam pembuatan yoghurt susu sapi terhadap uji organoleptik.

\section{MATERI DAN METODE}

\section{Materi}

Susu sapi yang digunakan dalam penelitian ini berupa susu sapi fresh milk (Chimory) sebanyak 9 liter dan kelapa hijau muda sebanyak 10 buah. Peralatan yang digunakan berupa parang, baskom, sendok, kompor, panci, pisau, toples, cup plastik, alumunium foil, dan bakteri starter berupa Lactobacillus bulgaricus dan Stertococcus termophillus.

\section{Waktu dan tempat penelitian}

Penelitian ini dilaksanakan pada bulan Januari hingga Maret 2020 di Laboratorium Teknologi Hasil Ternak dan Mikrobiologi Fakultas Peternakan
Universitas Udayana Jl. P. B Sudirman Denpasar.

\section{Rancangan percobaan}

Rancangan percobaan yang digunakan dalam penelitian ini berupa Rancangan Acak Lengkap (RAL) dengan menggunakan tiga perlakuan dan lima ulangan. Adapun perlakuan tersebut ialah Po: Inkubator berupa wadah vakum biasa (toples), P1: Inkubator berupa kelapa hijau muda (Cocos nucifera L.) tanpa daging, P2: Inkubator berupa kelapa hijau muda (Cocos nucifera L.) berisi daging.

\section{Prosedur penelitian}

Proses yang dilakukan pada saat pembuatan yogurt yaitu: susu sapi dipasteurisasi pada suhu $85^{\circ} \mathrm{C}$ selama 30 menit kemudian susu tersebut didiamkan hingga suhunya menjadi $45^{\circ} \mathrm{C}$. Setelah suhunya menurun kemudian ditambahkan mikroba starter sebanyak $3 \%$ dari susu yang digunakan dan diaduk sampai homogen. Apabila susu dan starternya telah homogen, kemudian masing-masing inkubator diisi dengan 600 $\mathrm{ml}$ susu tersebut selanjutnya ditutup hingga rapat agar terbentuk ruang anaerob dan diinkubasikan selama 24 jam pada suhu ruang (Ginting dan Pasaribu, 2005).

\section{Variabel yang diamati}

Variabel yang diamati berupa sifat organoleptik yang meliputi warna, aroma, citarasa, tekstur, dan penerimaan keseluruhan. Dalam memperoleh hasil dari penelitian ini dibutuhkan 25 orang panelis semi terlatih sebagai penguji organoleptik dari produk yang dihasilkan (Soekarto, 2002).

\section{Analisis data}

Analisis yang digunakan dalam penelitian ini ialah berupa uji Kruskal Wallis dan apabila menunjukkan perbedaan yang nyata $(\mathrm{P}<\mathrm{O}, 05)$ diantara perlakuan, maka analisis tersebut dilanjutkan dengan uji MannWhitney (Steel dan Torrie, 1995).

\section{HASIL DAN PEMBAHASAN}

Hasil yang diperoleh dari uji organoleptik (warna, aroma, citarasa, tekstur dan penerimaan keseluruhan) terhadap yoghurt susu sapi yang diinkubasi dalam wadah yang berbeda dapat dilihat pada Tabel 1 .

Hasil uji organoleptik terhadap warna yoghurt susu sapi yang diinkubasi menggunakan inkubator berbeda menunjukkan pengaruh yang tidak berbeda nyata. Hal ini membuktikan bahwa penggunaan kelapa hijau muda (Cocos nucifera L.) sebagai inkubator alami dalam proses pembuatan yoghurt susu sapi tidak memberikan pengaruh nyata terhadap warna yang dihasilkan. Pada umumnya, warna yoghurt berasal dari kandungan 
Tabel 1. Nilai uji organoleptik yoghurt susu sapi dalam inkubator yang berbeda

\begin{tabular}{ccccc}
\hline \multirow{2}{*}{ Peubah } & \multicolumn{4}{c}{ Perlakuan $^{(1)}$} \\
\cline { 2 - 4 } & PO & P1 & P2 & \\
\cline { 2 - 5 } Warna & $3,52^{\mathrm{a}(2)}$ & $3,76^{\mathrm{a}}$ & $3,76^{\mathrm{a}}$ & 0,09 \\
Aroma & $3,20^{\mathrm{a}}$ & $3,60^{\mathrm{a}}$ & $3,60^{\mathrm{a}}$ & 0.10 \\
Citarasa & $3,24^{\mathrm{a}}$ & $3,40^{\mathrm{a}}$ & $3,44^{\mathrm{a}}$ & 0.10 \\
Tekstur & $3,20^{\mathrm{a}}$ & $3,44^{\mathrm{ab}}$ & $3,88^{\mathrm{b}}$ & 0.11 \\
Penerimaan keseluruhan & $3,36^{\mathrm{a}}$ & $3,60^{\mathrm{a}}$ & $3,64^{\mathrm{a}}$ & 0.10 \\
\hline
\end{tabular}

Keterangan:

1 Perlakuan P0 : Inkubator berupa wadah vakum biasa (toples)

Perlakuan P1 : Inkubator berupa kelapa hijau muda (Cocos nucifera L.) tanpa daging Perlakuan P2 : Inkubator berupa kelapa hijau muda (Cocos nucifera L.) berisi daging

2 Nilai dengan huruf yang berbeda pada baris yang sama menunjukkan berbeda nyata $(P<0,05)$

3 SEM adalah "Standard Error of Treatment Means"

$\beta$-karoten pada hijauan pakan yang dikonsumsi oleh ternak sehingga susu yang dihasilkan akan mengandung lemak yang cenderung berwarna kuning (Ginting dan Pasaribu, 2005). Devianti et al. (2018), menyatakan hal yang serupa bahwa warna susu yang baik ialah putih kekuningan karena didalamnya terkandung lemak susu. Walaupun data statistik menyatakan hasil yang tidak berbeda nyata, namun nilai rata-rata pada yoghurt susu sapi yang diinkubasi menggunakan kelapa hijau muda (Cocos nucifera L.) sebagai inkubatornya lebih besar dibandingkan dengan yoghurt susu sapi yang diinkubasi menggunakan wadah vakum biasa (toples). Hal ini dipengaruhi oleh adanya tambahan lemak yang terkandung dalam kelapa hijau muda (Cocos nucifera L.) sehingga yoghurt yang dihasilkan lebih berwarna.

Aroma merupakan sensasi gabungan antara bau dan rasa selama mengkonsumsi sesuatu (Miwada et al., 2006). Susu memiliki sifat lemak yang mudah menyerap aroma dilingkungan sekitarnya (Devianti et al., 2018), namun dalam hal ini lemak tersebut belum mampu menyerap aroma yang terdapat dalam inkubator karena lemak tersebut terhidrolisis oleh bakteri asam laktat sehingga tidak dapat mempengaruhi aroma pada yoghurt susu sapi walaupun diinkubasi menggunakan kelapa hijau muda (Cocos nucifera L.). Hal ini sesuai dengan pernyataan Nurminabari et al. (2018) yang menyatakan bahwa, yoghurt memiliki aroma khas yang berasal dari berbagai asam yang terbentuk salah satunya berasal dari lemak dimana lemak tersebut akan dihidrolisis oleh bakteri asam laktat menjadi asam organik. Menurut Effendi (2001) dan Roswita et al. (2007), aroma yang khas pada yoghurt terbentuk akibat adanya Lactobacillus bulgaricusyang menghasilkan asetaldehid sedangkan Streptococcus thermophillusakan menghasilkan asam laktat, senyawa diasetil, dan asetoin yang akan membentuk citarasa pada yoghurt (Lusiastuti et al., 1995).

Menurut Septiana (2002), kualitas susu fermentasi dipengaruhi oleh adanya penambahan zat lain kedalam susu. Hal serupa juga dikemukakan oleh Heriyadi (2016) yang menyatakan bahwa, penggunaan mikroorganisme yang berbeda, bahan, dan/atau proses yang dilakukan dalam pembuatan susu fermentasi akan menghasilkan produk dengan rasa dan karakteristik yang berbeda. Menurut Udiyani (2012), penambahan air kelapa hijau pada susu fermentasi memberikan rasa manis dan segar terhadap susu fermentasi. Citarasa yang dihasilkan oleh yoghurt susu sapi yang diinkubasi menggunakan kelapa hijau muda (Cocos nucifera L.) cenderung lebih masam dan lebih disukai oleh panelis dibandingkan dengan yoghurt susu sapi yang diinkubasi menggunakan wadah vakum biasa (toples) walaupun menunjukkan hasil yang tidak berbeda nyata. Hal tersebut sesuai dengan pernyataan Wahyudi dan Samsundari (2008) yang menyatakan bahwa, rasa asam yang segar dan tekstur yang kompak pada yoghurt diakibatkan oleh adanya kandungan asam yang tinggi serta tidak mengandung alkohol. Menurut Yupardhi et al. (2015), kurangnya intervensi manusia dalam proses pembuatan yoghurt secara alami akan menghasilkan keamanan serta rasa yang baik.

Yoghurt susu sapi yang diinkubasi menggunakan kelapa hijau muda (Cocos nucifera L.) sebagai inkubatornya memberikan tekstur yang padat serta homogen namun lembut seperti puding sedangkan yoghurt susu sapi yang diinkubasi menggunakan wadah vakum biasa (toples) memiliki tekstur yang lebih encer dan tidak homogen sehingga kurang disukai oleh panelis. Menurut Badan Standarisasi Nasional Indonesia (2009), penampakan dan konsistensi yoghurt bersifat padat seperti puding (tidak encer) dan homogen. Tekstur semi padat dan kental pada yoghurt disebabkan oleh adanya koagulasi protein susu yang membentuk gel sehingga menyerupai puding (Rukmana, 2001). Hal ini menunjukkan bahwa penggunaan kelapa hijau muda (Cocos nucifera L.) sebagai inkubator alami dapat mempengaruhi tekstur pada yoghurt susu sapi karena selama proses fermentasi berlangsung susu memperoleh tambahan lemak yang bersumber dari kelapa hijau muda (Cocos nucifera L.). Pengaruh tersebut sesuai dengan pernyataan Ginting dan Pasaribu (2005) yang mengemukakan bahwa, yoghurt dengan tekstur paling padat terbentuk dari susu kerbau karena memiliki kandungan lemak yang lebih tinggi dibandingkan jenis susu lainnya. Aktivitas Lactobacillus yang menghubungkan kasein susu antara satu dengan yang lainnya pada saat proses fermentasi berlangsung akan mempengaruhi tekstur dadih. Hal ini dapat dilihat pada tumpukan lemak yang terdapat dipermukaan dadih. Tumpukan lemak yang banyak menunjukkan bahwa masa dadih yang terbentuk bersifat kompak, begitu pula dengan sebaliknya (Sepriadi et al., 2012). 
Perbedaan nilai yang diberikan oleh panelis terhadap penerimaan keseluruhan yoghurt susu sapi menunjukkan hasil yang tidak berbeda nyata, namun dari hasil rataan yang diperoleh menunjukkan bahwa yoghurt susu sapi yang diinkubasi menggunakan kelapa hijau muda (Cocos nucifera L.) memiliki nilai yang lebih tinggi dibandingkan dengan yoghurt susu sapi yang diinkubasi menggunakan wadah vakum biasa (toples). Hal ini disebabkan karena, penggunaan kelapa hijau muda (Cocos nucifera L.) sebagai inkubator pada pembuatan yoghurt susu sapi merupakan suatu inovasi yang baru serta panelis yang digunakan dalam melakukan uji organoleptik merupakan panelis semi terlatih yang berada dilingkungan Universitas Udayana sehingga panelis belum dapat membedakan hal-hal spesifik pada variabel yang diamati. Menurut Standar Nasional Indonesia (1992), standar kualitas yoghurt yakni tekstur semi padat hingga kental serta aroma khas dan memiliki rasa asam pada yoghurt.

\section{SIMPULAN}

Berdasarkan hasil penelitian, dapat disimpulkan bahwa panelis lebih menyukai tekstur yoghurt susu sapi yang diinkubasi menggunakan kelapa hijau muda (Cocos nucifera L.) berisi daging. Secara keseluruhan, yoghurt susu sapi yang diinkubasi menggunakan inkubator berbeda memiliki kualitas yang sama dengan nilai sebesar 3,36-3,64 (mengarah ke kriteria suka). Penggunaan kelapa hijau muda (Cocos nucifera L.) berisi daging sebagai inkubator alami pembuatan yoghurt susu sapi memberikan nilai terbaik pada uji orgenoleptik yoghurt susu sapi.

\section{DAFTAR PUSTAKA}

Almatsier, S. 2002. Prinsip Dasar Ilmu Gizi. PT Gramedia Pustaka Utama. Jakarta.

Badan Standardisasi Nasional Indonesia. 2009. Yoghurt. SNI 2981-2009. Jakarta.

Direktorat Gizi Departemen Kesehatan RI. 1981. Daftar komposisi bahan makanan. Bhratara Karya Aksara. Jakarta.

Devianti, A. W., Bambang. H., dan Sjafril. D. 2018. Identifikasi kualitas kesegaran susu sapi melalui pengolahan sinyal digital berdasarkan metode gabor wavelet dan klasifikasi support vector machine. E-Proceeding of Engineering. 2 (5): 2056-2063.

Effendi, M. H. 2001. Perbandingan kualitas yoghurt dari susu kambing dengan suhu pemerahan yang berbeda. Jurnal Media Kedokteran Hewan. 17 (3): 144-147.

Ginting, N., dan E. Pasaribu. 2005. Pengaruh temperatur dalam pembuatan yoghurt dari berbagai jenis susu dengan menggunakan Lactobacillus bulgaricus dan Streptococcus thermophilus. Jurnal Agribisnis Peternakan. 1 (2): 73-77.

Helferich, W. and D. Westhoff. 1980. All About Yoghurt. Prentice-Hall. Inc Englewood Cliffs. New Jersey.

Heriyadi, I. 2016. Kualitas Organoleptik dan Keasaman Susu Fermentasi yang Menggunakan Konsentrasi Sukrosa Berbeda. Skripsi. Fakultas Peternakan Universitas Hasanuddin. Makassar.

Hieronymus, B. S. 1998. Toga Tanaman Obat Keluarga, Kanisius: Yogyakarta.

Kurniati, Y. 2010. Kajian Penambahan Sari Ubi Jalar Sebagai Sumber Prebiotik Pada Susu Kelapa yang Difermentasi oleh Lactobacillus casei FNCC 0090. Disertasi. Fakultas Pertanian Universitas Lampung. Bandar Lampung.

Koswara, S. 2009. Teknologi Pembuatan Yoghurt. eBookPangan.com.

Lusiastuti, A. M., S. Prawesthirini., A. T. S. Estoepangestie., D. Raharjo., dan M. A Alamsjah. 1995. Diversifikasi Susu Kambing menjadi Produk Keju dan Yoghurt. Laporan Penelitian. Lembaga Penelitian Universitas Airlangga. Surabaya.

Miwada, I. N. S., S. A. Lindawati., dan W. Tatang. 2006. Tingkat efektivitas starter bakteri asam laktat pada proses fermentasi laktosa susu. Jurnal Indon.Trop. Anim.Agric. 31 (1): 32-35.

Nurminabari, I. S., Sumartini., dan Arifin, D. P. P. 2018. Kajian penambahan skim dan santan terhadap karakteristik yoghurt dari whey. Pasundan Food Technology Journal. 5 (1): 54-62.

Puspita, R. 2007. Perbandingan Sifat Fisika dan Kimia Minyak Kelapa dari Kelapa Hijau (Cocos nucifera L. var. Viridis) dan Kelapa Gading (Cocos nucifera L. var. Eburnea) yang Diperoleh Melalui Proses Enzimatik dengan Bonggol Buah Nanas (Ananas comosus (L). Merr). Skripsi. Fakultas Farmasi Universitas Airlangga. Surabaya.

Roswita, S., Hadi, S., dan Masniar, P. 2007. Pengaruh starter bakteri Lactobacillus bulgaricus, Streptococus thermopilus, dan Lactobacillus plantarum terhadap sifat mutu susu fermentasi. Seminar Nasional Teknologi Peternakan dan Veteriner.

Rukmana, H.R. 2001. Yoghurt dan Karamel Susu. Kanisius. Yogyakarta.

Sepriadi, S., U. Budi., N. Ginting. 2012. Perbaikan kualitas dadih susu kerbau murrah menggunakan bahan kemasan. Jurnal Peternakan Integratif. 1 (1): 19-33.

Septiana, Y. 2002. Peningkatan Aktivitas Sistem Laktoperoksidase pada Susu serta Pengaruhnya terhadap Susu Pasteurisasi dan Yoghurt. Skripsi. 
Fakultas Peternakan. Institut Pertanian Bogor. Bogor.

Soekarto, S. 2002. Penilaian Organoleptik untuk Industri Pangan dan Hasil Pertanian. Bharata Karya Aksara. Jakarta.

Standar Nasional Indonesia. 1992. Yoghurt. SNI - 29811992. Pusat Standarisasi Industri. Departemen Perindustrian. Jakarta.

Steel, C. J., dan J. H. Torrie. 1995. Prinsip dan Prosedur Statistik. PT. Gramedia. Jakarta.

Tamime, A.Y. and R. K. Robinson., 1989. Yoghurt Science and Technology. Pergamon Press. Oxford. England.

Udiyani, N. M. M. 2012. Evaluasi Hedonik Susu Fermentasi Berbasis Air Kelapa. Skripsi. Fakultas Peternakan. Universitas Udayana. Denpasar.

Usmiati, S dan Abubakar. 2009. Teknologi penanganan dan pengamanan susu segar dan olahannya. Seminar Nasional Hari Pangan Sedunia XXVII.

Wahyudi, A., dan S. Samsundari. 2008. Bugar dengan Susu Fermentasi. UMM Press. Malang.

Yupardhi, W. S., I. G. L. Oka., A. Pratiwi., I. N. S. Sutarpa., dan I. N. S. Miwada. 2015. Evaluation on performance of yoghurt used modern technology versus natural one. Animal Production. 17 (1): 56-61. 